Arab Univ. J. Agric. Sci., Ain Shams Univ., Cairo, Egypt

28(4), 1257-1270, 2020

Website: http://ajs.journals.ekb.eg

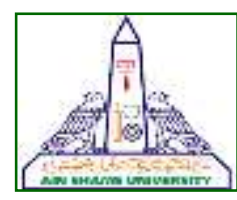

1257

\title{
Enhancing Tomato Plant Resistance Against Tobacco Mosaic Virus Using Riboflavin
}

\author{
Farida M Mahmoud ${ }^{\star}$, Ahmed M Bondok, Walaa Khalifa, \\ Fawzy Abo El-Abbas \\ Plant Pathology Dept, Fac of Agric, Ain Shams Univ, P.O. Box 68, Hadayek Shoubra, \\ 11241, Cairo, Egypt
}

*Corresponding author: Faridamohamed@agr.asu.edu.eg

Received 22 November, 2020

Accepted 5 December, 2020

\begin{abstract}
Plant systemic resistance induced by natural product is an alternative technique of disease management. Riboflavin (vitamin B2) usually used as abiotic elicitor to improve the plant immunity against different pathogens. This work aimed to explore the efficiency of three riboflavin concentrations $(0.5$, 2.5 , and $5 \mathrm{mM}$ ) to enhance resistance toward Tobacco Mosaic Virus (TMV) in tomato plants. Our results showed that exogenous application of $2.5 \mathrm{mM}$ riboflavin, 5 days before virus challenge was the most effective concentration, which provided a reduction in disease incidence and disease severity by $80 \%$ and $75 \%$, respectively. Furthermore, obtained results were confirmed by using DAS-ELISA test, which showed that concentration $2.5 \mathrm{mM}$ of riboflavin decreased the virus concentrations by $46.4 \%$ in treated-inoculated plants. It was remarked that exogenous application of $2.5 \mathrm{mM}$ riboflavin showed a positive effect on some plant growth parameters either in presence or absence of TMV challenge. The plant height and number of leaves per plant were significantly improved in treated- inoculated plants about $30 \%$ and in compared to the infected control $78 \%$. In time course investigation, $2.5 \mathrm{mM}$ riboflavin treatment reduced the virus symptoms particularly at $9^{\text {th }}$ day, where after the symptoms become evident. In addition, expression of phenylalanine ammonia-lyase (PAL) and pathogenesis-related protein (PR10), which are the markers of systemic acquired resistance (SAR), were rapidly increased in inoculated-treated tomato from 1-3 days after treatment. Moreover, the results of the biochemical changes analysis revealed that, the levels of the defense markers including peroxidase
\end{abstract}

(PO), and polyphenol oxidase (PPO) were increased four days after of treatment and reached maximum levels at 8 days in the treated-inoculated plants. In conclusion, it could be suggesting that riboflavin exerted a great influence on TMV disease, as indicated by reduction of disease symptoms as well as enhancement of biochemical changes in plant defense against infection with TMV.

Keywords: Tomato, Tobacco Mosaic Virus, Riboflavin, Systemic acquired resistance, Biochemical analysis

\section{Introduction}

Tobacco Mosaic Virus (TMV) is well-studied virus (Rybicki 2015, An et al 2019) which cause a destructive crop loss in many vegetable and ornamental crops throughout the world (Lv et al 2017). TMV infects commercially grown tomato worldwide, and seriously inflict the quality and yield (Waziri 2015, Zhao et al 2017). For the avoidance of TMV disease, different strategies were applied which couldn't have been effective. Over the years, an unconventional management strategy has been applied in an effort to mitigate the extensive economic damage caused by TMV (Srivastava et al 2015). One solution might be focused on systemic acquired resistance (SAR), which plays very important role in the improving of resistance of plant against different agents (Kong et al 2018, Guo et al 2020). SAR mentions to a distinct signal transduction pathway that is usually triggered through exogenous application of chemicals, leading to a long-term resistance to a wide variety of pathogenses (Dempsey and Klessig 2012, Lucas et al 2013). SAR mechanism has been 
associated with improved, more efficient activation of response and primed resistance to stimulating biotic and abiotic stress (Conrath 2011). Numerous researches reported vitamins and their essential role towards the development of a safe and sustainable resistance in plant (Aranega-Bou et al 2014, Boubakri et al 2016).

Riboflavin (vitamin $B_{2}$ ) is recognized as an essential bio-sensitized product in plants and many microorganisms. It contributes many ethnobotanical uses and pharmacological activities (Deng et al 2014), and modulate several different physiological processes such as growth of plant and defense responses (Taheri and Tarighi 2011). Several studies have illustrated the effect of riboflavin in improving disease resistance against a broad-spectrum pathogen (Conrath 2011). Riboflavin is participated in the anti-oxidation (Perumal et al 2005), and peroxidation processes (Nazarul et al 2006), which both enhance the reactive oxygen reactions and other plant defense mechanisms (Nie and Xu 2016). Moreover, treatment with riboflavin induces defensive responses in plants instead of directly inhibition of pathogens growth (Aver'yanov et al 2000, Taheri and Höfte 2006). Recently, riboflavin activates PRgenes in Arabidopsis and induces SAR to pathogens (Boubakri et al 2013, Deng et al 2014).

With this background the present study aims to evaluate the riboflavin for its resistance eliciting efficiency against TMV infection in tomato plants as a classical SAR system as well as an investigation some of the important biochemical and molecular events involved in the process.

\section{Materials and methods}

\subsection{Plant materials}

Twenty-five-days old seedlings of Solanum lycopersicum var. Super Strain B were transplanted individually into $20 \mathrm{~cm}$ pots, containing mixtures of clay and sand $(1: 3 \mathrm{v} / \mathrm{v})$. The plants were kept in the greenhouse at $23-25^{\circ} \mathrm{C}$ and photoperiod of $16 \mathrm{~h}$. They were irrigated as needed and fertilized as usual.

\subsection{Source of the virus}

The used strain of TMV was kindly provided by Virus Lab., Department of Agriculture Microbiology, Faculty of Agriculture, Ain shams University. Inoculum consisted of symptomatic leaves of TMV-infected tobacco were ground $(1 / 3 \mathrm{w} / \mathrm{v})$ in $25 \mathrm{mM}$ sodium phosphate buffer $(\mathrm{pH}$ 7.0) containing $0.002 \mathrm{M}$
EDTA and celite $\left(0.1 \mathrm{mg} \mathrm{ml}^{-1}\right)$ as abrasive (Chen et al 2017).

\subsection{Inducing chemical and experimental set up}

Riboflavin (Biomatic Corporation) was diluted in distilled water containing $0.02 \% \mathrm{v} / \mathrm{v}$ Tween-20 to a series of concentrations $(0.5,2.5,5 \mathrm{mM})$ and sprayed onto leaf surfaces of 3-4 leaf stage tomato plants until run-off. Sterile distilled water containing $0.02 \% \mathrm{v} / \mathrm{v}$ Tween-20 was used as negative control. Plants were kept at $22^{\circ} \mathrm{C}$ and $65 \%$ humidity. Five days later, plants were divided into groups and treated as follows: (1) plants treated with sterilized distilled water only [Healthy control]; (2) plants inoculated with TMV; (3) plants treated with $0.5 \mathrm{mM}$ riboflavin; (4) plants treated with $0.5 \mathrm{mM}$ riboflavin and inoculated with TMV; (5) plants treated with $2.5 \mathrm{mM}$ riboflavin; (6) plants treated with $2.5 \mathrm{mM}$ riboflavin and inoculated with TMV; (7) plants treated with $5 \mathrm{mM}$ riboflavin and (8) plants treated with $5 \mathrm{mM}$ riboflavin and inoculated with TMV. Each group consisted of ten replicates. All experimental plants were arranged in completely randomized block design and the experiments were carried out in two successive growing seasons.

\subsection{Plant growth characters}

At the end of the experiment, plants were harvested and some morphological parameters such as plant height and leaf number per plant were assessed.

\subsection{Assessment of disease resistance}

The level of TMV resistance was evaluated based on disease incidence and severity of symptoms. Disease incidence was assessed as the percentage of plants that showing typical virus symptom 30 days post inoculation. The disease severity was evaluated using a scale according to Wang et al (2009) while the severity index was estimated using the following formula as described by Yang et al (1996).

Disease Severity $(\%)$
$=\frac{\sum(\text { disease grade } \times \text { number of plants in each grade })}{(\text { Total number of plants } \times \text { highest disease grade })} \times 100$

Leaf samples were taken 3 weeks later for measuring virus concentration using bioassay and ELISA techniques. 


\section{Enhancing Tomato Plant Resistance Against Tobacco Mosaic Virus Using Riboflavin}

\subsection{Quantification of TMV infectivity}

Virus infectivity has been quantified in treatedinfected plants and infected control plants by extracting their crude sap and inoculation on Nicotiana glutinosa leaves. Number of developed local lesions, seven days later on inoculated plants were counted and calculated for the using the following formula as described by Prasad et al (1995).

$\%$ Inhibition $=$ (number of local lesions of treated sample / number of local lesions of control) $\times 100$

\subsection{Determination of TMV concentration}

TMV accumulation in the leaves was determined by DAS-ELISA (Clark and Adams 1977) using polyclonal antibodies (Bioreba AG, Switzerland) according to the provided instructions. Samples were considered positive if the ELISA absorbance value was greater than twice for comparable negative control samples (Córdoba-Sellés et al 2007).

\subsection{Time course of SAR by riboflavin}

The concentration of $2.5 \mathrm{mM}$ riboflavin was the most effective one, so this concentration was used for this study. Tomato plants were inoculated with TMV after 0 to 21 days of riboflavin treatment. Control plants were similarly treated with sodium acetate buffer (20mM, pH 5.2). Symptoms and inhibition percentage of virus infection were daily recorded till $21^{\text {th }}$ day later to express resistance induced. Moreover, the virus concentration was determined during the time course using DAS-ELISA.

\subsection{Gene expression analysis of $P A L$ and $P R 10$}

Tomato leaf samples (100mg) were collected at $0,3,6$ and 12 hours after riboflavin treatments (2.5Mm). Total RNA was extracted by total RNA purification kit (Jena Bioscience, Germany) according to the manufacturers' instructions. Presence or absence of pathogensis related protein (PR10) - and PAL- genes was established by RT-PCR, using pair of specific primers (PAL-Forward, 5'-AAGCTGATGTTCGCGCAGTTCT-3', and PAL-reverse, 5'- AAACCATAGTCCAAGCTCGGGT-3'), (PR10-Forward, 5'-AAGGAGATGTTCTTGGAGACAAACTTG-3', and PR10- reverse, 5'- AGCGTAGACAGAAGGATTGGCG-3'). The expression of the gene of interest was normalized, relative to that of the housekeeping actin genes (Actin- Forward, 5'-
TCATACGGTCAGCAATAC-3; Actin- reverse, 5ATGTGGATATCAGGAAGGA-3. In order to obtain cDNA, mRNA was reverse transcribed using a onestep RTPCR kit (QIAGEN, Hilden, Germany). PCR reactions were subjected in a thermal Eppendorf master cycler (T100TM thermal cycler, BIO-RAD) under the following conditions: reverse transcription at $50 \stackrel{\circ}{\circ}$ for $30 \mathrm{~min}$, followed by denaturation at $94^{\circ} \mathrm{C}$ for $15 \mathrm{~min}, 30$ cycles of $94^{\circ} \mathrm{C}$ for $30 \mathrm{~s}, 60^{\circ} \mathrm{C}$ for $30 \mathrm{~s}$ and $72^{\circ} \mathrm{C}$ for $30 \mathrm{~s}$, and a final extension of $72^{\circ} \mathrm{C}$ for $1 \mathrm{~min}$. The RT-PCR products were checked through electrophoresis on 1.5\% agarose gel and ethidium bromide stained bands were visualized under UV light.

\subsection{Biochemical changes associated with ribo-} flavin treatment

Peroxidase (PO), and polyphenol Oxidase (PPO) activities were estimated spectrophotometric ally using the appropriate wavelength for each enzyme. Samples were taken of healthy control, infected control, treated plant, and treated- infected plants at different period $0,4,8,9,10$, and 13 days after inoculation. Crude enzyme was extracted according to Mofunanya et al (2016).

Peroxidase activity was assayed according to Wang's method (Wang 2006). PO activity was analyzed by measuring oxidation level of guaiacol at $470 \mathrm{~nm}$ per mg protein per minute, using a spectrophotometer (Hitachi U-1800, Japan). Each sample was tested 3 times.

Meantime, Polyphenol oxidase activity was determined according Ngadze et al (2012) in which 1 $\mathrm{ml}$ of leaf extracts of each control plant were mixed with $3 \mathrm{ml}$ of freshly prepared reaction mixture containing $0.05 \mathrm{M}$ buffer sodium phosphate and $0.1 \mathrm{M}$ catechol solution ( $\mathrm{pH} 6.5)$. The absorbance of the mixture was measured after $3 \mathrm{~min}$ at a wavelength of $420 \mathrm{~nm}$. PPO activity is presented as the change in Unit $\mathrm{mg}^{-1}$ protein ${ }^{-1} \mathrm{~min}^{-1}$.

\subsection{Statistical analysis}

All the experiments were performed twice. There were presented as mean $\pm S E$ of at least three independent replicates for each determination. Analyses of variance were carried out using ANOVA. Least significant difference (LSD) was employed to test for significant difference between treatments at P-value < 0.05 (Gomez and Gomez 1984). 


\section{Results}

\subsection{Plant growth characters}

Initial symptoms were observed on the infected tomato plants as discoloration and mosaic symptoms 20 days after inoculation. However, these symptoms appeared on riboflavin treated plants 30 dpi. Riboflavin treatments have generally enhanced the growth of both non-inoculated and TMV-inoculated plants, with maximal effect to $2.5 \mathrm{mM}$ riboflavin. In absence of TMV, riboflavin applied at $2.5 \mathrm{mM}$ significantly increase plant height by 38.59 and as compared to healthy control Fig 1. Number of leaves per plant 0.5 and $2.5 \mathrm{mM}$ riboflavin treated plants were also increased by about 42 and $72 \%$ compared with healthy control Fig 2. In absence of $\mathrm{TMV}$, riboflavin applied at $2.5 \mathrm{mM}$ significantly increase Leaves number by 78.04 and as compared with healthy control Fig 2.

The infected plants showed substantial reductions of $20.35 \%$ in their height compared to non-inoculated plants (healthy control) Fig 1. However, 0.5 and $2.5 \mathrm{mM}$ riboflavin treated showed the same significant increase in the plant height of TMV-inoculated plants by 30.39 and compared to infected control plants Fig 1. Moreover, Leaf number per plant was significantly increased by 78.04 in TMVinfected plants grown at $2.5 \mathrm{mM}$ riboflavin compared with infected control Fig 2.

\subsection{Assessment of disease resistance}

Elicitors are a common feature of induced resistance to disease, allow enhancement of active defense mechanisms against different stresses (Chakraborty and Acharya 2017). Previous studies reported the efficiency of riboflavin to improve the plant immunity against different pathogens (Boubakri et al 2016). In the present study, the potential activity of three riboflavin concentrations $(0.5,2.5$, $5 \mathrm{mM}$ ) was assessed to enhance the resistance of tomato plants against TMV.

Data in Fig $\mathbf{3}$ showed the effect of treatment with different concentrations of riboflavin on TMV disease incidence 30 days after inoculation with TMV. Riboflavin treating plants with 0.5 and $2.5 \mathrm{mM}$ significantly $(P \leq 0.05)$ reduced TMV incidence by about
60 and $80 \%$, respectively, as compared to infected control plants Fig 3. Whereas, disease severity was decreased by $62.5,75$, and $25 \%$ in plants sprayed with $0.5,2.5$, and $5 \mathrm{mM}$ riboflavin, respectively as compared to the infected control Fig 4.

\subsection{Quantification of TMV infectivity}

As shown in Fig 5, all TMV crude sap extracted of treated plants exhibited different degrees of reduction in local lesions number formed on N. glutinosa, relative to TMV crude sap extracted from infected control. Treated plants ( 0.5 and $5 \mathrm{mM})$ showed a remarkable reduction in infection with TMV reached to $37.5 \%$, and $16.67 \%$, respectively. However, $2.5 \mathrm{mM}$ riboflavin treated plants exhibited excellent reduction in TMV activity with decreased number of local lesions (87.5\%). It was very clear that $2.5 \mathrm{mM}$ riboflavin played an important role for reducing TMV activity rather than other concentrations Fig 5.

\subsection{Determination of TMV concentration}

Virus concentration assessed by DAS-ELISA revealed that, TMV accumulation was greatly reduced in all treated- infected plants but it was not completely suppressed Fig 6. TMV quantitation data from two experiments indicated that the 0.5 and $2.5 \mathrm{mM}$ riboflavin treatments typically caused a decrease in TMV concentrations by 44 and $61.18 \%$, respectively, as compared to the infected control Fig 6.

\subsection{Time course of SAR by riboflavin}

As shown in Fig 7, application of $2.5 \mathrm{mM}$ riboflavin before TMV challenge led to increase the plant resistance gradually from the 1 st day. It reached a plateau between $6^{\text {th }}$ and $8^{\text {th }}$ day, peaked after $9^{\text {th }}$ day and finally declined gradually till the $21^{\text {th }}$ day of challenge Fig 7. Disease incidence and disease severity were decreased in treated-inoculated plants by 33.3 and $20 \%$ at $9^{\text {th }}$ day, respectively Fig 7 . The same trend of reduction in disease symptoms of riboflavin treated plants was confirmed by DASELISA, which revealed a significant inhibition in the virus concentrations at $9^{\text {th }}$ day Fig 8. 


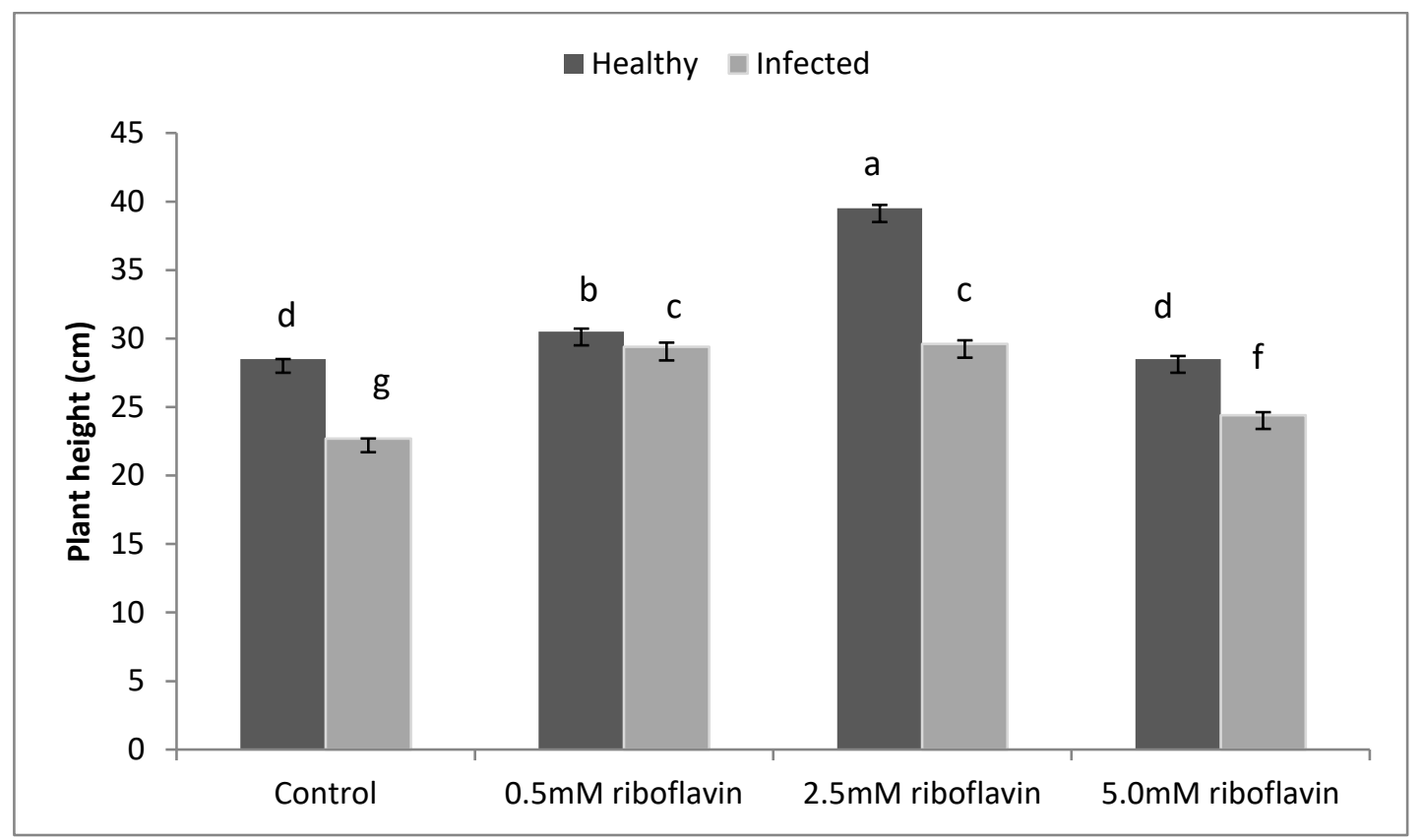

Fig 1. Plant height of tomato plants in response to riboflavin in deferent concentration and were inoculated 5 days later. Ten plants were used per treatment and data obtained 30 days after inoculated. The same letter is not significant at $p \leq 0.05$ and standard error of mean calculated

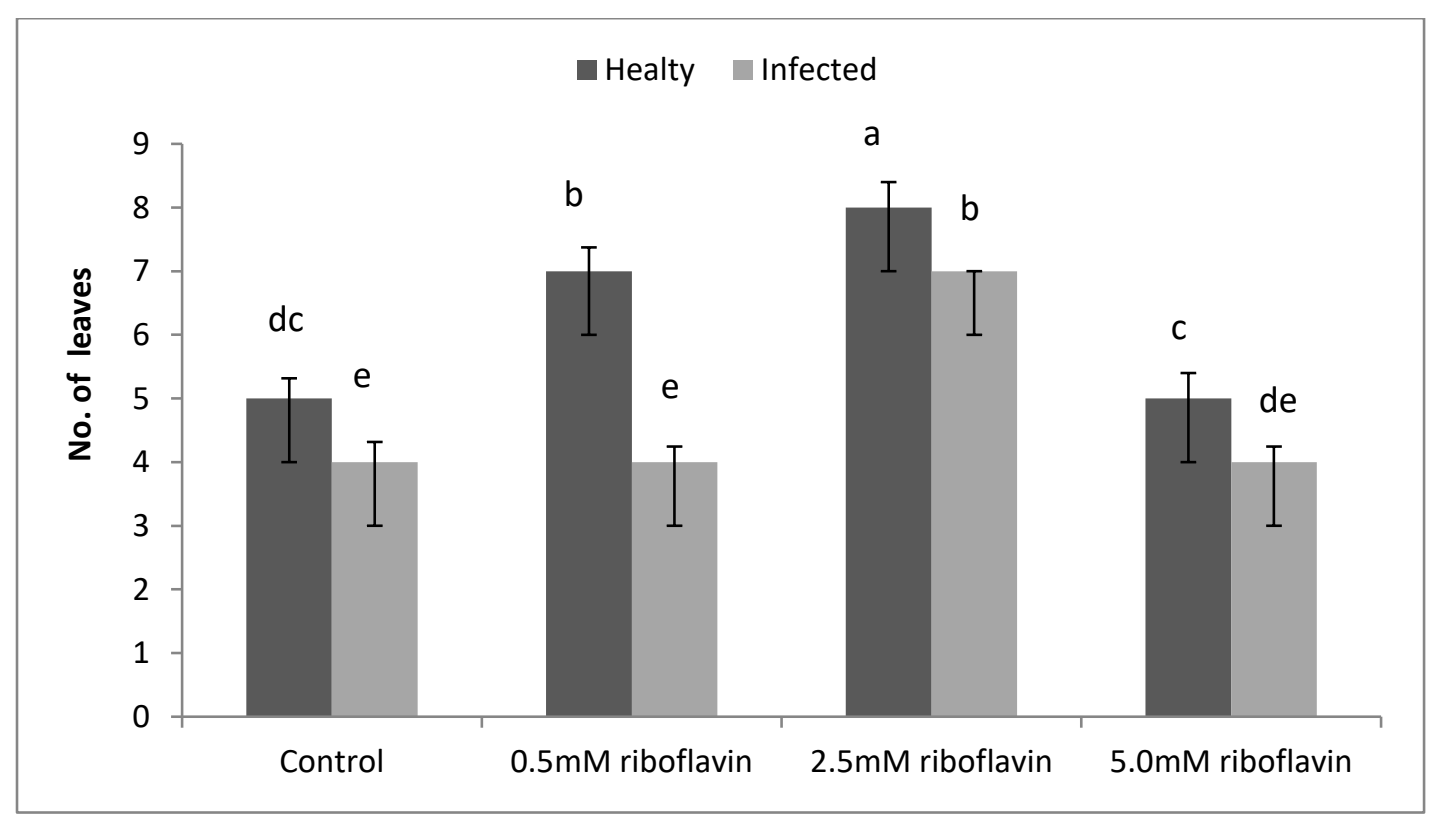

Fig 2. Number of leaves of tomato plants in response to riboflavin in deferent concentration and were inoculated 5 days later. Ten plants were used per treatment and data obtained 30 days after inoculated. The same letter is not significant at $p \leq 0.05$ and standard error of mean calculated 


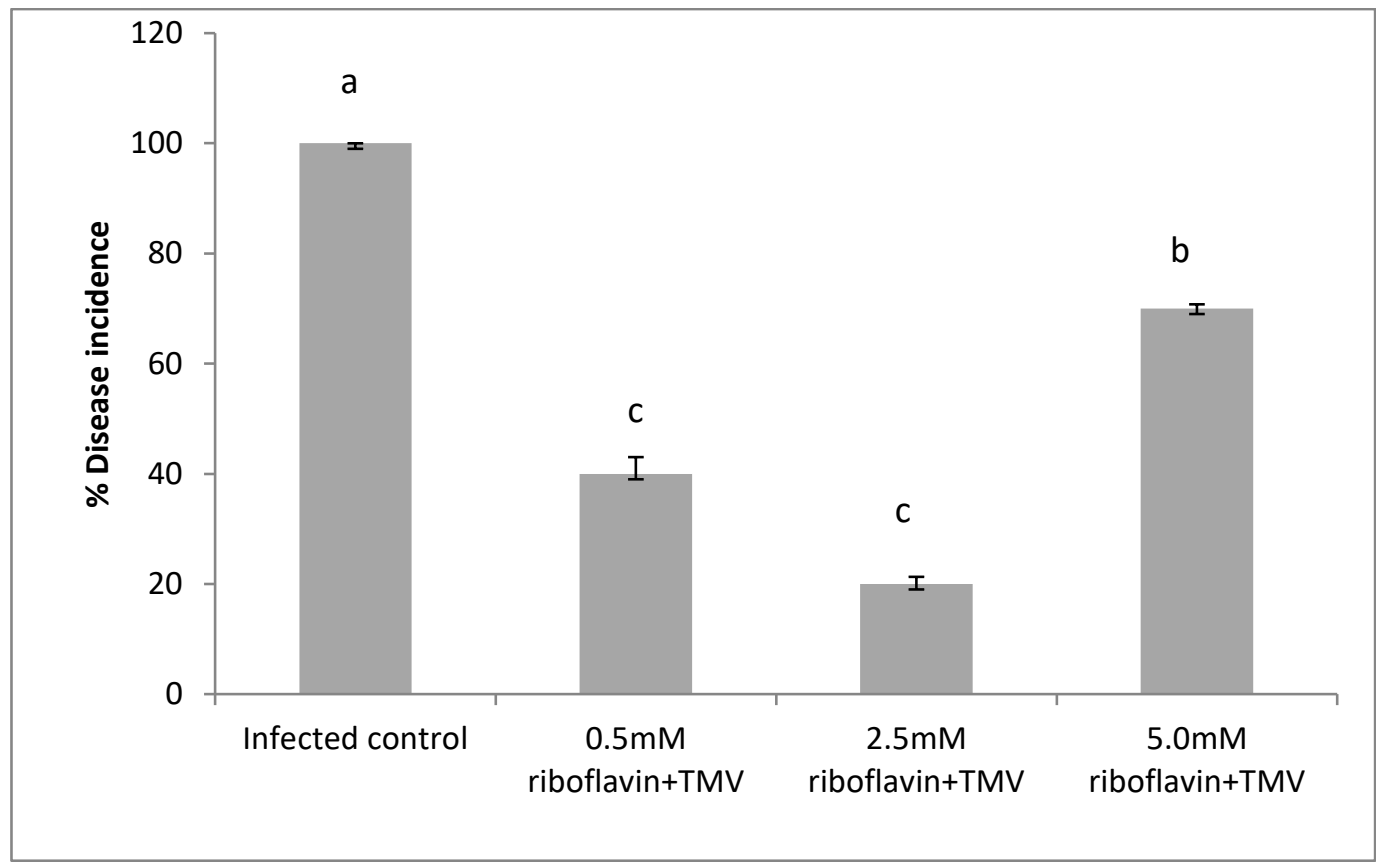

Fig 3. TMV incidence on tomato plants 35 day after challenge as affected by different concentration with riboflavin. Ten plants were used per treatment. The same letter is not significant at $p \leq 0.05$ and standard error of mean calculated

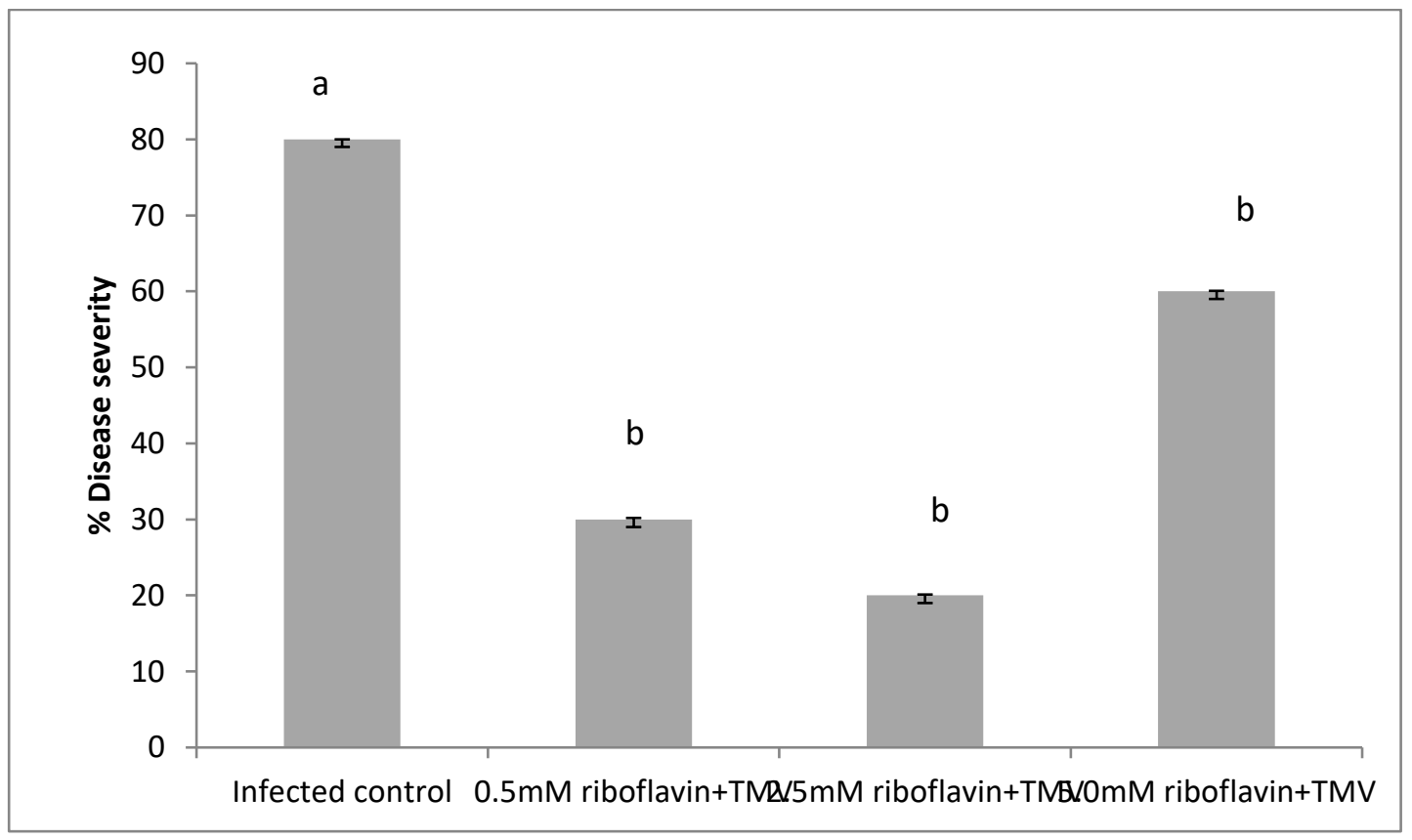

Fig 4. TMV severity on tomato plants 35 day after challenge as affected by different concentration with riboflavin. Ten plants were used per treatment. The same letter is not significant at $p \leq 0.05$ and standard error of mean calculated 


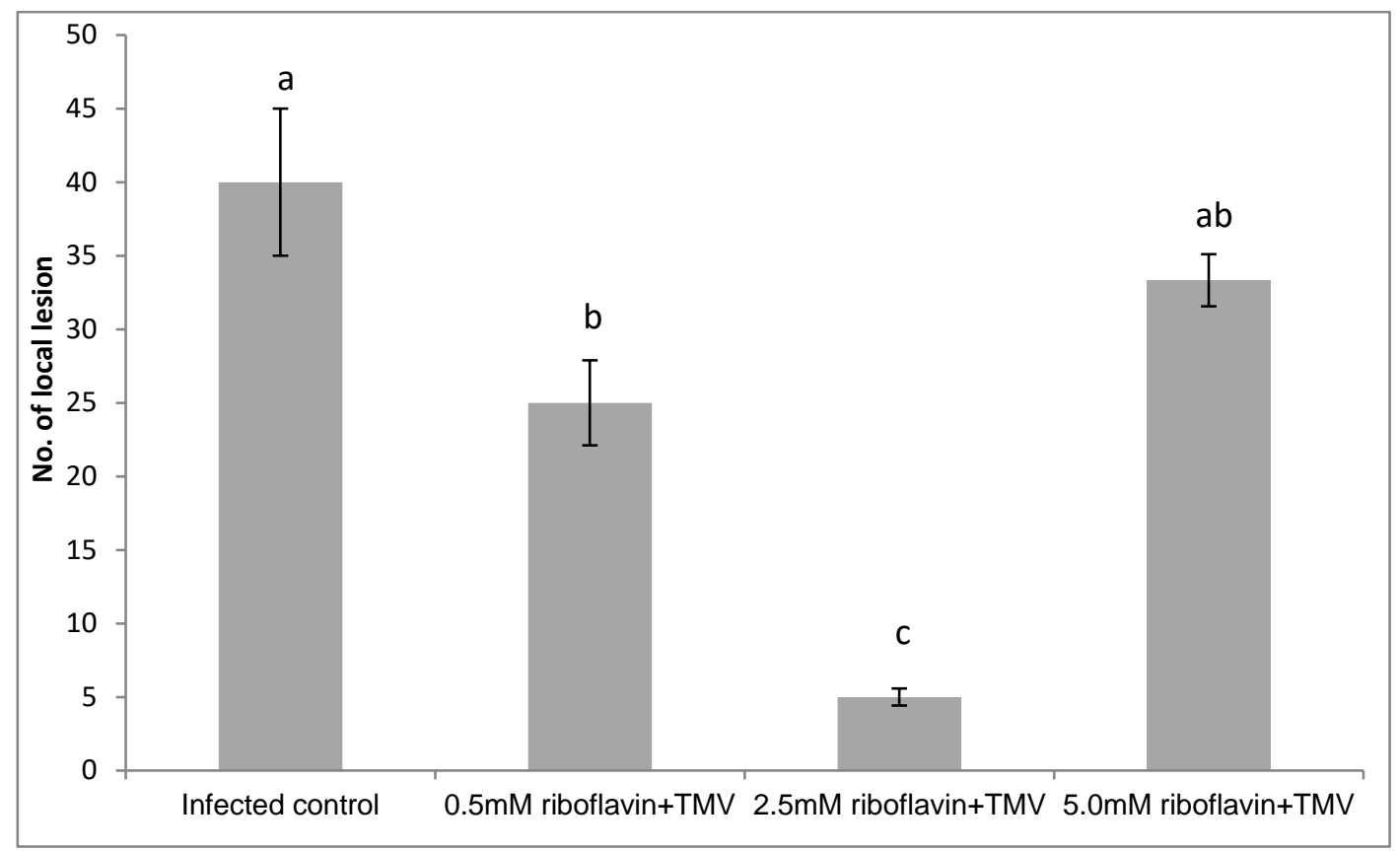

Fig 5. Effect of riboflavin on TMV infectivity according to formation of local lesion on $N$. glutinosa plant. Samples to prepare the infection sap were collected from treated tomato plants at 14 days after inoculation with TMV. Each experiment was repeated twice. Five plants were used per treatment and average number of local lesions was determined from 10 leaves each for treated. The same letter is not significant at $p \leq 0.05$ and standard error of mean calculated

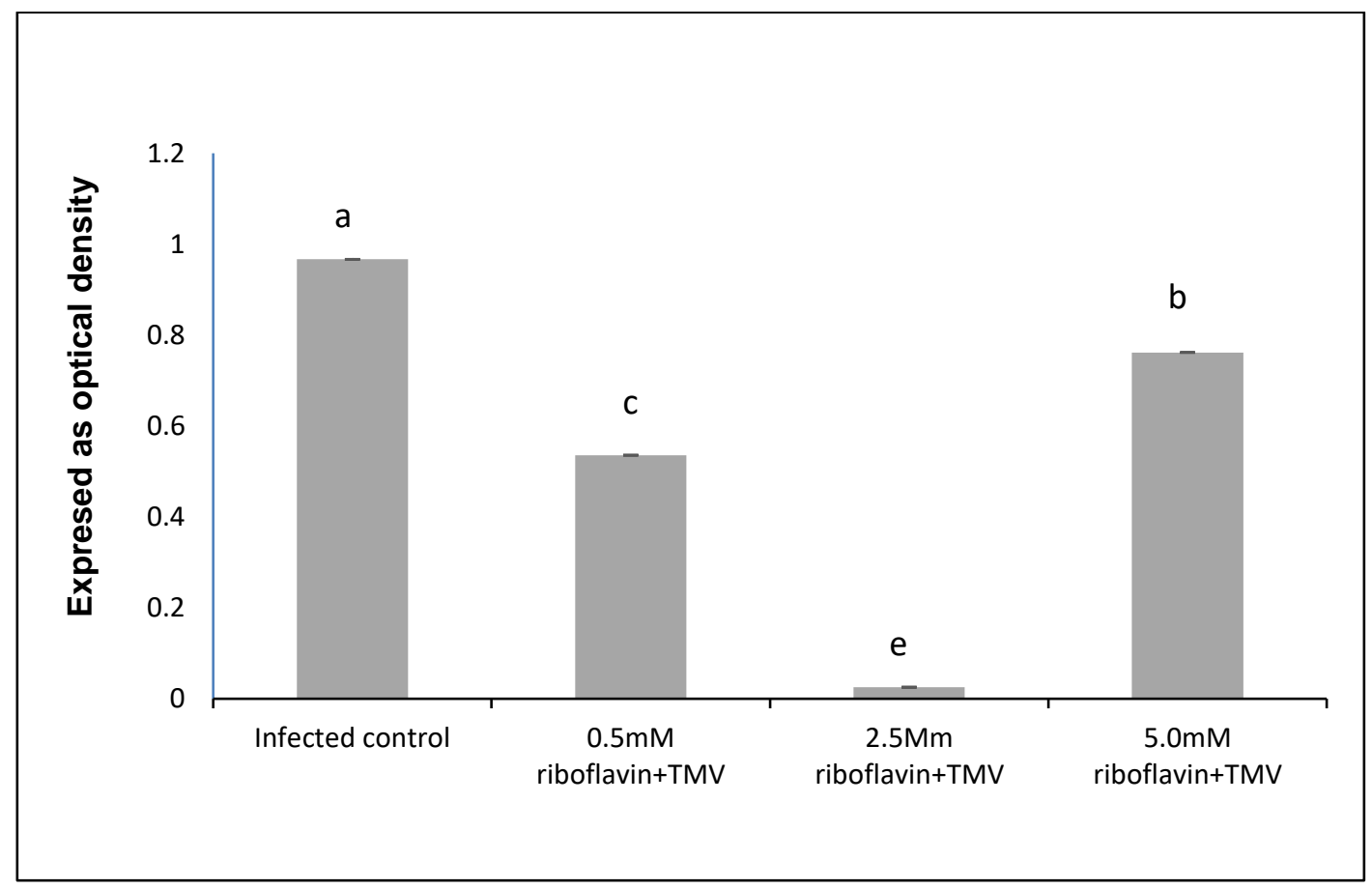

Fig 6. Effectiveness of riboflavin on virus concentration at 14 days after inoculation in tomato plants using DAS-ELISA. Each experiment was repeated twice. Ten plants were used per treatment and the same letter is not significant at $p \leq 0.05$ and standard error of mean calculated 


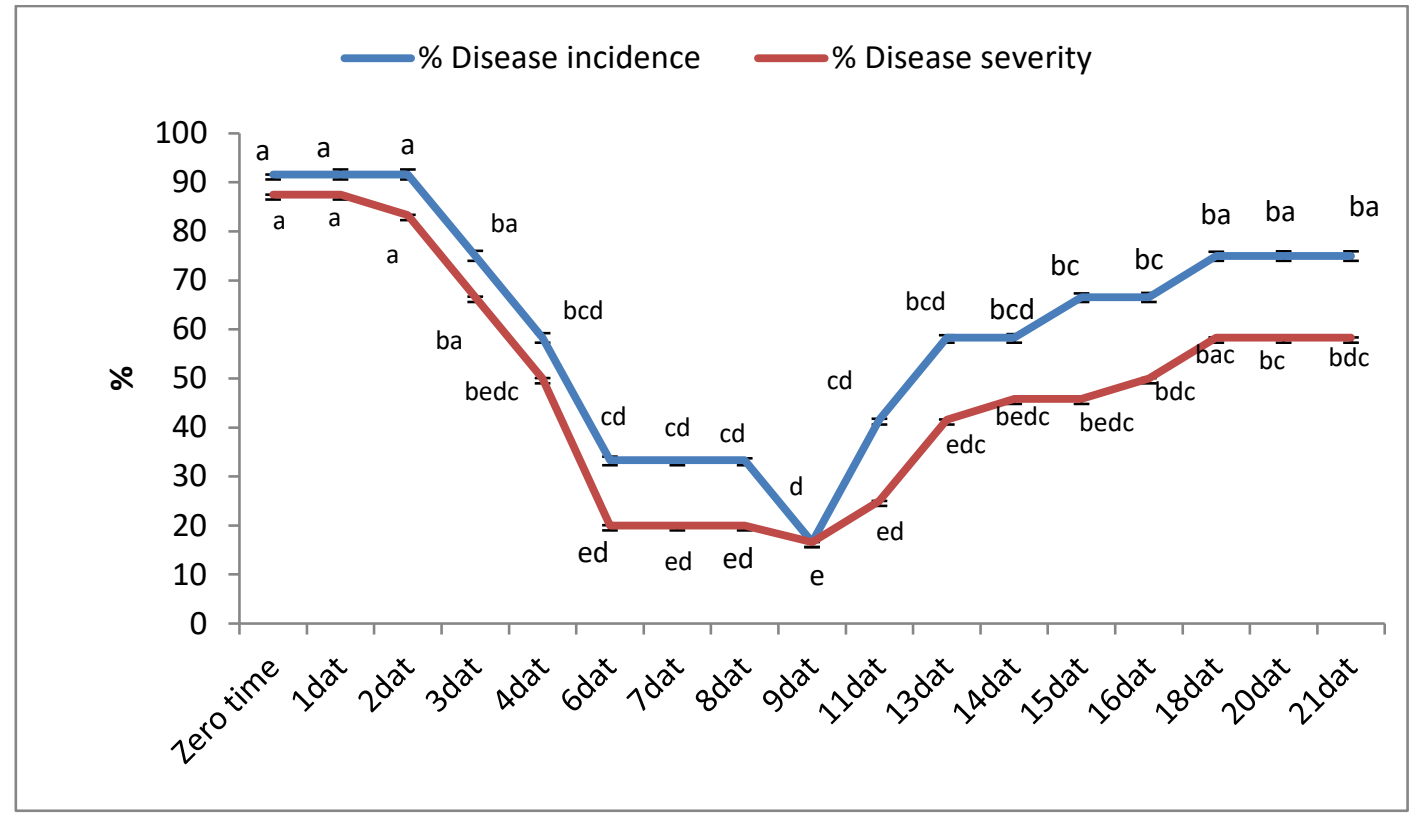

Fig 7. Time course riboflavin $(2.5 \mathrm{mM})$ on TMV development infection and severity. Ten plants were used per treatment and data obtained at 35 day after challenge. The same letter is not significant at $p \leq 0.05$ and standard error of mean calculated

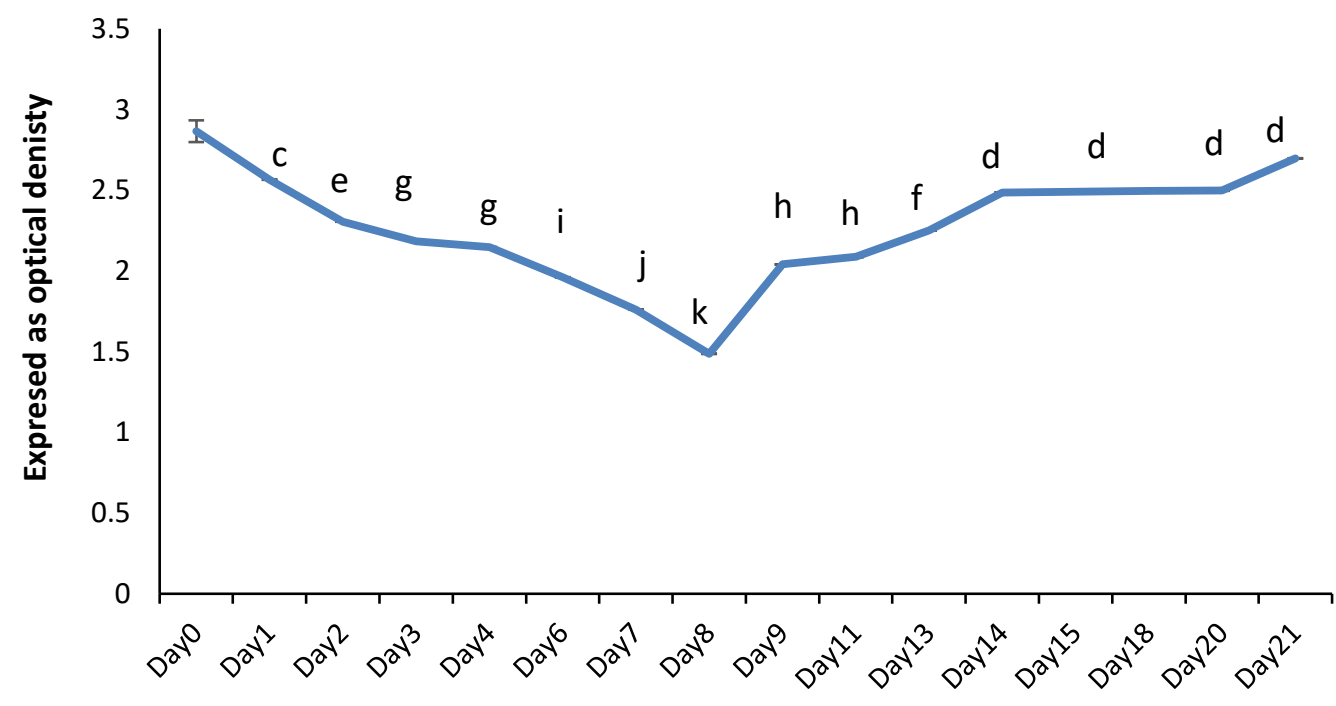

Fig 8. Time course riboflavin $(2.5 \mathrm{mM})$ on TMV concentration at 14 days after inoculation in tomato plants using DAS-ELISA. Each experiment was repeated twice. Ten plants were used per treatment and the same letter is not significant at $p \leq 0.05$ and standard error of mean calculated 


\subsection{Gene expression analysis of $P A L$ and $P R 10$}

Data illustrated in Fig 9 showed that $2.5 \mathrm{mM}$ riboflavin treatment markedly induced the accumulation of PAL-mRNA in the beginning 3 hours and raised at $6 \mathrm{~h}$, followed by a slightly decrease at 12 h. Similarly, PR10 accumulation was notable increased at 3 and $6 \mathrm{~h}$ and waked at $12 \mathrm{~h}$ after treatment Fig 9. Interestingly, the accumulation of $P R$ 10 , one of the members of PR10 proteins, has displayed significantly phosphorylation, which enhanced resistance against TMV in Capsicum annuum as previously recorded (Ali et al 2018). Whereas, there was no remarkable different in the mRNA level of actin at any time points.

\subsection{Biochemical changes associated with ribo- flavin treatment}

Results in Fig 8 revealed that, PO activity was improved and significantly peaked at maximum level at $8^{\text {th }}$ day in both non-infected and TMV-infected plants after the riboflavin treatment Fig $\mathbf{1 0}$. This increased activity remained stable till $9^{\text {th }}$ day, and then was followed by sharp declining trend during the time course. Peroxidase activity in treated inoculated plants was 1.6 and 1.4 times higher than those of healthy and infected controls at the $8^{\text {th }}$ day, respectively Fig 10.

Likewise, accumulation of polyphenol oxidase (PPO) activities was gradually increased in the first 4 days, and then raised sharply till 8 day in riboflavin treated plants in response to TMV infection. After nine days of elicitation, enzyme activities were gradually diminished. Results in Fig 9 denote further that, PPO was slightly activated in treated- non inoculated plants over healthy and infected control plants during the time course Fig 11.

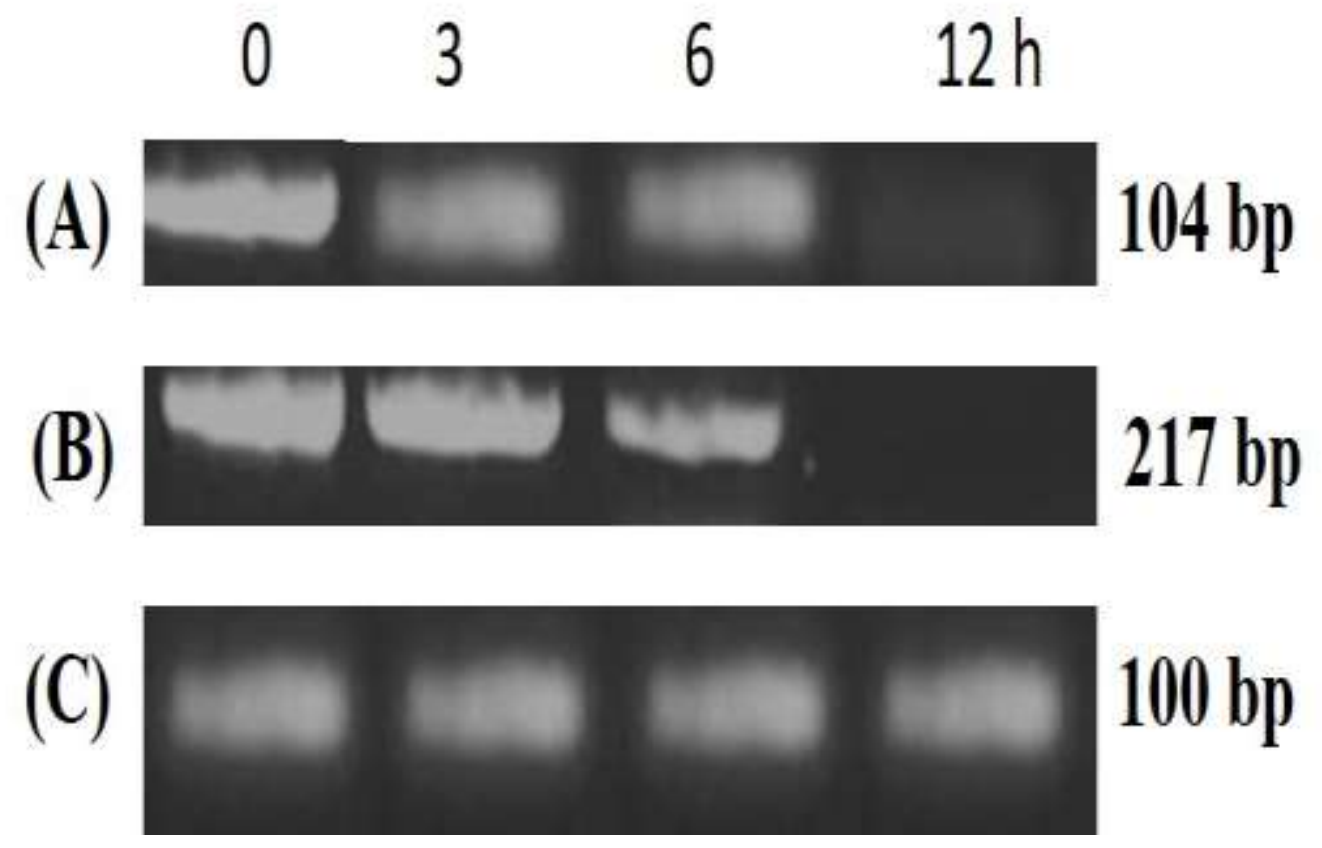

Fig 9. RNA expression level of $P A L$ and $P R 10$ genes in tomato plants at different time points $(0,3,6,12$ h) after exogenous application with $2.5 \mathrm{mM}$ riboflavin. A, Transcription level of PAL at expected molecular weight (104 bp). B, Transcription level of expression of PR-10 at expected molecular weight (217 bp). C, Expression of actin gene as housekeeping gene. 


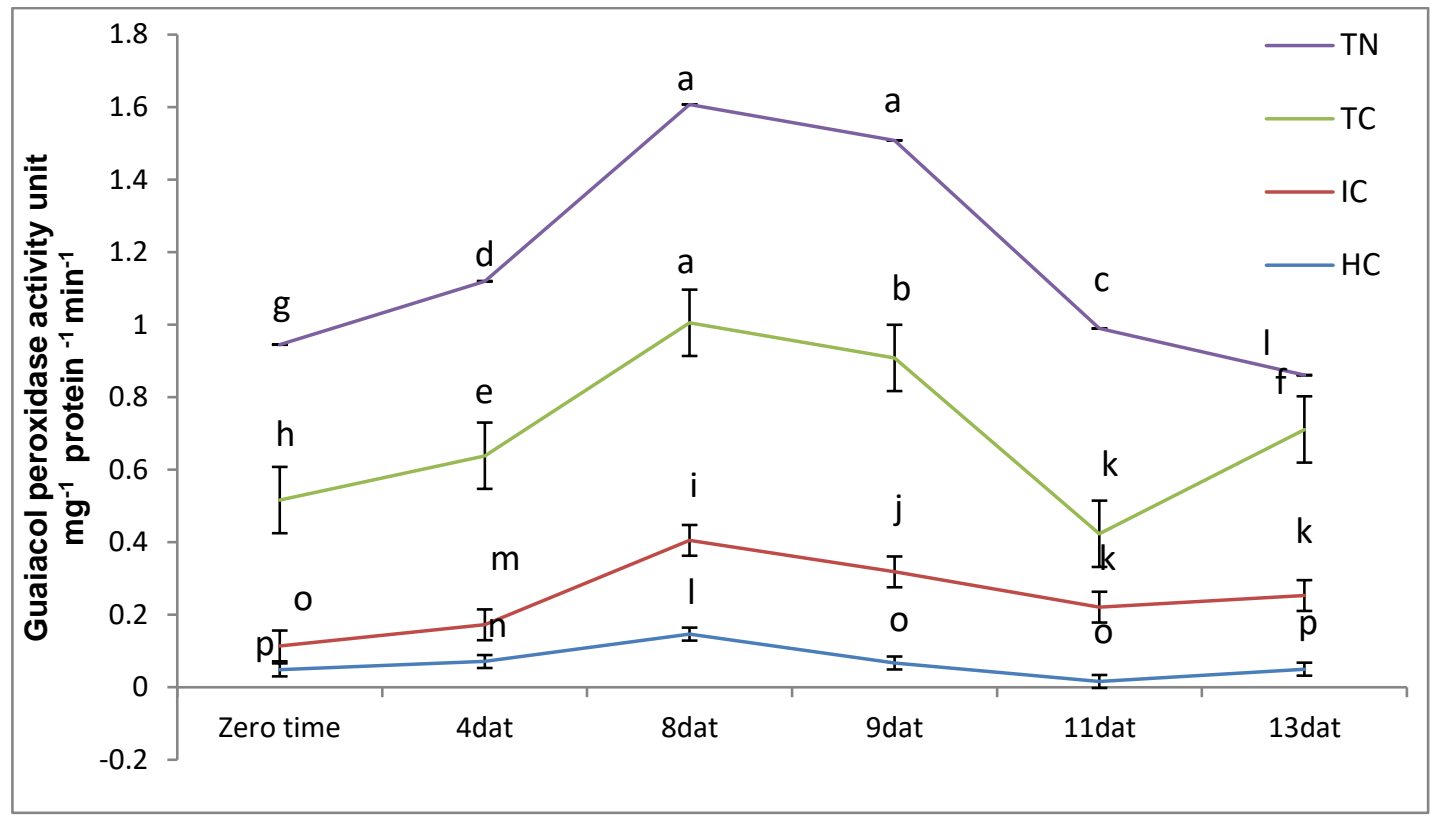

Fig 10. Effect of treatment with $2.5 \mathrm{mM}$ of riboflavin on peroxidase activity in tomato plants. HC: Healthy control, IC: Infected control (non- treated inoculated plants), TC: treated (2.5Mm) non-inoculated, TN: treated inoculated plants with $2.5 \mathrm{mM}$ of riboflavin, Optical density at $470 \mathrm{~nm}$. Data obtained at least from 10 plants / treatment. The same letter is not significant at $p \leq 0.05$ and standard error of mean calculated

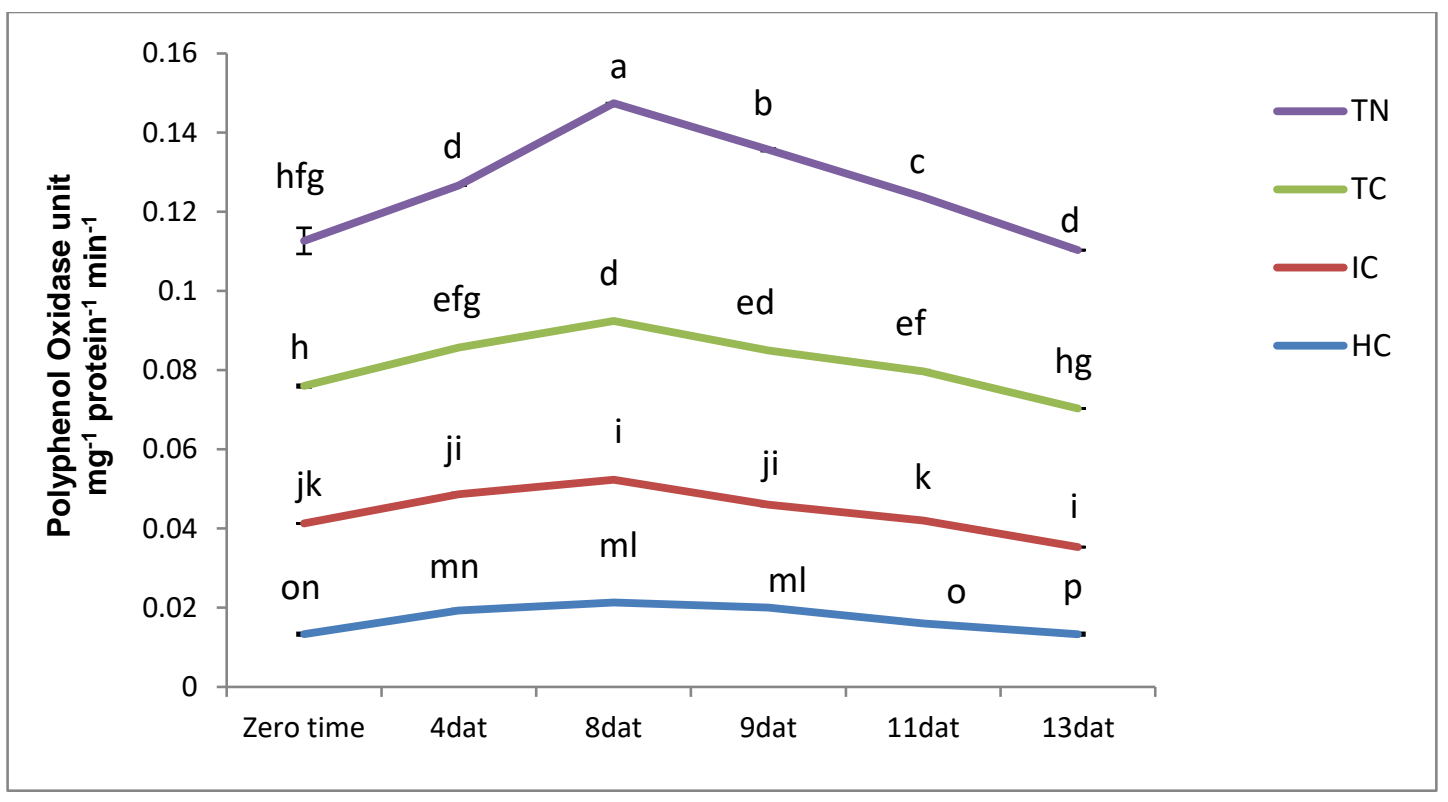

Fig 11. Effect of treatment with $2.5 \mathrm{mM}$ of riboflavin on Polyphenol Oxidase activity in tomato plants. HC: Healthy control, IC: Infected control (non- treated inoculated plants), TC: treated $(2.5 \mathrm{Mm})$ non-inoculated, TN: treated inoculated plants with $2.5 \mathrm{mM}$ of riboflavin, Optical density at $420 \mathrm{~nm}$. Data obtained at least from 10 plants/ treatment. The same letter is not significant at $p \leq 0.05$ and standard error of mean calculated 


\section{Discussion}

Elicitors are a common feature of induced resistance to disease, allow enhancement of active defense mechanisms against different stresses (Chakraborty and Acharya 2017). Previous studies reported the efficiency of riboflavin to improve the plant immunity against different pathogens (Boubakri et al 2016). In the present study, the potential activity of three riboflavin concentrations $(0.5,2.5$, $5 \mathrm{mM}$ ) was assessed to enhance the resistance of tomato plants against TMV. Obtained results revealed that spraying tomato plants with $(2.5 \mathrm{mM})$ riboflavin five days before inoculation were reduced mosaic symptoms on treated plants to $25 \%$ Fig 4 . This result was in agreement with those of Zhang et al (2009), who reported the enhancement resistance of tobacco plant against Alternaria alternata and TMV after riboflavin treatment. Our results are also in accordance with those of Torkey (2016), who found a significant effect of $2 \mathrm{mM}$ riboflavin in reducing TMV symptoms on sweet pepper when applied just before viral infection. In addition, $2.5 \mathrm{mM}$ riboflavin treatment showed a significant suppressive influence on virus infectivity and virus concentration compare with other treatments Figs $\mathbf{5}$ and $\mathbf{6}$. This indicates that exogenous application of $2.5 \mathrm{mM}$ riboflavin before virus inoculation could enhance resistance against TMV in both L.L. host and host plants. These results are consistent with the findings of Torkey (2016) who observed the efficiency of low concentration of riboflavin and thiamin in reducing TMV infectivity and its concentration in Capsicum annuum. On the other hand, obtained results in time course experiment indicated that, disease severity and virus concentration were reduced and reached its minimum levels 6 to 8 days after treating with $2.5 \mathrm{mM}$ riboflavin Figs 7 and 8 . Similar observations were also reported by Abdel- Monaim (2011) who observed the inhibition of disease severity of charcoal rot disease 5 to 7 days after riboflavin treating soybean plants.

Several studies have been explained how riboflavin can prime systemic plant defenses (Wang et al 2013; Polacios et al 2014). According to Darwish et al (2017), Riboflavin is necessary cofactor in diversing metabolic pathways that lead directly to promote plant growth and enabling higher resistance to pathogen attack. Obtained data denoted that, plant high and number of leaves were improved in each of non-inoculated and inoculated plant after treatment with $2.5 \mathrm{mM}$ riboflavin Figs 1 and 2. This assertion is also supported by the findings of Bondok and Thabet (2016) who reported that $1 \mathrm{mM}$ riboflavin foliar application enhanced tomato plant vigor and triggered plant defense TMV infection. Furthermore, numerous researchers demonstrated the role of riboflavin in priming disease defense reactions that include the expression of pathogenesis related (PR) proteins (Nie and $\mathrm{Xu}$ 2016). In present work, the transcription level of PR10 gene, as a molecular marker for SAR, was gradually increased in treated plants and peaked at 6 hours after foliar application of $2.5 \mathrm{mM}$ riboflavin Fig 9. Interestingly, the accumulation of CaPR-10, one of the members of PR10 protein, has displayed significantly phosphorylation, which enhanced resistance against TMV in Capsicum annuum as previously recorded (Ali et al 2018). Likewise, expression level of the PAL gene, a key enzyme of the phenylpropanoid pathway, was increased after riboflavin treatment at all-time points Fig 9. These results are in agreement with Taheri and Tarighi (2010) who explained the role of riboflavin to enhance plant defense responses through up regulation of $P A L$ in rice- $R$. solani pathosystem. The literature obviously mentioned that riboflavin mediates many bioprocesses related with the increasing of peroxidation (Ji et al 2014). Our investigation cleared notable elevation of PO and PPO activities in both non-infected and TMV-infected plants at the $8^{\text {th }}$ day after treatment with $2.5 \mathrm{mM}$ riboflavin Figs 10 and 11. Same trend of results obtained by Abdel- Monaim (2011) who mentioned that treatment with either thiamine or riboflavin can induce elicitation of the PO and PPO activity in soya bean plants and reached maximum levels at 8 and 6 respectively. Bondok and Thabet (2016) also observed higher PO activity in riboflavin treated tomato plant at $7^{\text {th }}$ day after TMV inoculation. These results also are in line with Torky (2016) who observed enhancement in the activities of $\mathrm{PO}$ and $\mathrm{PPO}$ in $C$. annuum plants sprayed with thiamin and riboflavin providing resistance against TMV. Altogether, these results suggest that riboflavin might be involved in enhancing of plant defense responses.

\section{Conclusion}

In conclusion, this study provides an efficient approach that priming tomato defense responses against TMV infection. Foliar application with $2.5 \mathrm{mM}$ riboflavin before TMV challenge decreased disease severity and virus concentration, which associated with activation a series of defense responses including increasing in the expression of 
defense-related genes (PR10 - and PAL genes) and the activities of antioxidant enzyme (PO and PPO).

\section{References}

Abdel-Monaim, M (2011) Role of riboflavin and thiamine in induced resistance against charcoal rot disease of soybean. Afr J Biotechnol 10, 1084210855.

Ali, S; Ganai, B; Kamili, A; Bhat, A; Mir, A; Bhat, J; Tyagi, A; Islam, S; Mushtaq, M; Yadav, P; Bawat, S; Grover, A (2018) Pathogenesis-related proteins and peptides as promising tools for engineering plants with multiple stress tolerance. Microb Res 212-213, 29-37.

An, M; Zhou, T; Guo, Y; Zhao, X; Wu, Y (2019) Molecular regulation of host defense responses mediated by biological anti-TMV agent Ningnanmycin. Viruses 11, $815 \mathrm{p}$.

Aranega-Bou, P; Leyva, M; Finiti, I; Garcia-Agustin, P; Gonzàlez-Bosch, C (2014) Priming of plant resistance by natural compounds hexanoic acid as a model. Front Plant Sci 5, 1-12.

Aver'yanov, A; Lapikova, V; Nikolaev, O; Stepanov, A (2000) Activated control of rice blast disease by riboflavin and roseflavin. Biochemistry 65, 12921298.

Bondok, A; Thabet, M (2016) Riboflavin and humic acid induced resistance in tomato against Tobacco Mosaic Vrus (TMV). Middle East J Agric Res 5, 868880.

Boubakri, H; Chong, J; Poutaraud, A; Schmitt, C; Bertsch, C; Mliki, A; Masson, J; SoustreGacougnolle, I (2013) Riboflavin (Vitamin B2) induces defence responses and resistance to Plasmopara viticola in grapevine. Eur J Plant Pathol 136, 837-855

Boubakri, H; Gargouri, M; Mliki, A; Brini, F; Chong, J; Jbara, M (2016) Vitamins for enhancing plant resistance. Planta 244, 529-543.

Chakraborty, N; Chandra, S; Acharya, K (2017) Biochemical basis of important of defense in tomato plant against Fusarium wilt by $\mathrm{CaCl}_{2}$. Physiol $\mathrm{Mol}$ Biol Plant Patho 23, 581-596.

Chen, L; Zou, W; WU, G; Lin, H; I, D (2017) Tobacco alpha-expansin EXPA4 plays a role in Nicotiana bethamiana defence Tobacco Mosaic Virus. Planta 247, 355-368.
Clark, M; Adams, A (1977) Characteristics of the microplate method of enzyme-linked immunosorbent assay for the detection of plant viruses. J gen Virol $34,475-483$.

Conrath, U (2011) Molecular aspects of defence priming. Trends Plant Sci 16, 524-531.

Córdoba-Sellés, M; García-Rández, A; AlfaroFernández, A; JordáGutiérrez, C (2007) Seed transmission of Pepino Mosaic Virus and Efficacy of Tomato Seed Disinfection Treatments. Plant Dis 91, 1250-1254.

Darwish, M; Nasser, R; Abdel-Aziz, N; Abdel-Aal, A (2017) Riboflavin minimizes the deleterious effects of salinity stress on growth, chloroplast pigments, free proline, activity of antioxidant enzyme catalase and leaf anatomy of Tecoma capensis (Thumb.) Lindl. Middle East J Agr Res 6, 757-765.

Dempsey, D; Klessig, D (2012) SOS - too many signals for systemic acquired resistance? Trends in Plant Sci 17, 538-545.

Deng, B; Jin, X; Yang, Y; Lin, Z; Zhang, Y (2014) The regulatory role of riboflavin in the drought tolerance of tobacco plants depends on ROS production. Plant Growth Regul 72, 269-277.

Gomez, K; Gomez, A (1984) Statistical Procedures for Agricultural Research, $2^{\text {ed }}$, John wiley and sons, New York, 680 pp.

Guo, W; Yan, H; Ren, X; Tang, R; Sun, Y; Wang, Y; Feng, J (2020) Berberine induces resistance against Tobacco Mosaic Vrus in tobacco Pest Manag Sci 76, 1804-1813.

Ji, H; Zhu, Y; Tian, S; Xu, M; Tain, Y; Li, L; Wang, H; Hu, L; Ji, Y; Ge, J; Wen, W; Dong, H (2014) Down regulation of leaf flavin content induces early flowering and photoperiod gene expression in Arabidopsis. BMC Plant Biol 14, 1-13.

Kong, H; Shin T; Kim, T; Ryu, C (2018) Stereoisomers of the bacterial volatile compound 2,3-butanediol differently elicit systemic defense responses of pepper against multiple viruses in the field. Front Plant Sci 9, 90-102.

Lucas, J; Pajerowska-Mukhtar, K (2013) Salicylic acid: an old hormone up to new tricks. Mol Plant Path 14, 623-634.

Lv, X; Ren, Z; Li, D; Ruan, B; Li, Q; Chu, M; Ai, C; Liu, D; Mo, K; Cao, H (2017) Discovery of novel double pyrazole Schiff base derivatives as anti-tobacco 


\section{Enhancing Tomato Plant Resistance Against Tobacco Mosaic Virus Using Riboflavin}

mosaic virus (TMV) agents. Chin Chem Lett 38, 377-382.

Mofunanya, A; Owolabi, A; Nkang, A (2016) Time Course Evaluation of the Activities of Some Enzymes in Telfairia Mosaic Virus Infected Ecotypes of Telfairia occidentalis Hook. Plant Pathol J 15, 8694.

Ngadze, E; Icishahayo, D; Coutinho, T; van der Waals, J (2012) Role of polyphenol oxidase, peroxidase, phenylalanine ammonia lyase, chlorogenic acid, and total soluble phenols in resistance of potatoes to soft rot. Plant Dis 96, 186-192.

Nazarul, H; lyad, A; Imrana, N (2006) Photodynamic inactivation of trypsin by the aminophyllineriboflavin system: involvement of hydroxyl radical. Med Sci Mon 12, 283-289.

Nie, S; Xu. H (2016) Riboflavin-induced resistance requires the mitogen-activated protein kinase 3 and 6 in Arabidopsis Thaliana. Pols ONE 11, 1-19.

Palacios, O; Bashan, Y; de-Bashan, L (2014) Proven and potential involvement of vitamins in interactions of plants with plant growth-promoting bacteria-an overview. Biol Fertil Soils 50, 415-432.

Perumal, S; Shanthi, P; Sachdanandam, P (2005) Augmented Efficacy of Tamoxifen in Rat Breast Tumorigenesis When Gavaged Along with Riboflavin, Niacin, and Coq10: Effects on Lipid Peroxidation and Antioxidants In Mitochondria. Chem Biol Interac 152, 49-58.

Prasad, V; Srivastava, S; Varsha, Versma, H (1995) Two basic proteins islated from Clerodendrum inerme Gaertn are inducers of systemic antiviral resistance in susceptible plants. Plant Sci 110, 73-82.

Rybicki, E (2015) A top ten list for economically important plant viruses. Arch Virol 160, 17-20.

Srivastava, A; Srivastva, S; Prasad, V (2015). Systemic antiviral resistance indued in papaya by cap34 , aresistance inducing protein from Clerodendrum aculeatum, is associated with a proteinaceous virus inhibitory activity. J Plant Pathol 97, 45-54.
Taheri, P; Höft, M (2006) Riboflavin induces resistance in rice against Rhizoctonia sheath disease by activating signal transduction pathways leading to upregulation of rice cationic peroxidase and formation of lignin as structural barrier. Communications in Agric Appl Biolo Sci 71, 255-258.

Taheri, P; Tarighi, S (2010) Riboflavin induces resistance in rice against Rhizoctonia solani via jasmonate-mediated priming of phenylpropanoid pathway. J plant Physiol 167, 201-208.

Taheri, P; Tarighi, S (2011) A survey on basal resistance and riboflavin induced defense responses of sugar beet against Rhizoctonia solani. J Plant Physiol 186, 1114-1122.

Torkey, Z (2016) Vitamin B mediated priming of disease resistance and defence responses to Tobacco Mosaic Virus in Capsicum annuum L. plants. J Antivir Antiretrovir 8, 035-053.

Wang, S; Huijun, W; Junqing, Q; Lingli, M; Jun, L; Yanfei, X; Xuewen, G (2009) Molecular mechanism of plant growth promotion and induced systemic resistance to Tobacco Mosaic Virus by Bacillus spp. J Microbiol Biotechnol 9, 1250-1258.

Wang, L; Zhu, X; Liu, J; Chu, X; Jiao, J; Liang, Y (2013) Involvement of phospholipases C and D in the defense responses of riboflavin-treated tobacco cells. Protoplasma 250, 441-449.

Waziri, H. (2015) Plants As Antiviral Agents. J Plant Pathol Microbiol 6, 1-5.

Yang, X.; Liangyi, K; Tien, P (1996) Resistance of tomato infected with Cucumber Mosaic Virus satellite RNA to potato spindle tuber viroid. Ann Appl Biol 129, 543-555.

Zhang, S; Yang, X; Sun, M; Sun, F; Deng, S; Dong, $H$ (2009) Riboflavin induced priming for pathogen defense in Arabidopsis thaliana. J Integr Plant Biol 51, 167-174.

Zhao, L; Feng, C; Wu, K; Chen, W; Chen, Y; Hao, X (2017) Advances and prospects in biogenic substances against plant virus: A review. Pestic Biochem Physiol 135, 15-26. 


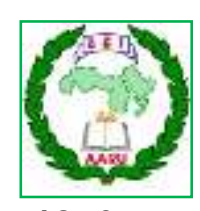

مجلة اتحاد الجامعات العربية للعلوم الزراعية، جامعة عين شمس، القاهرة، مصر

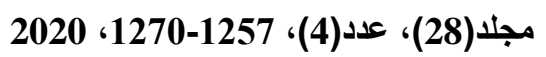

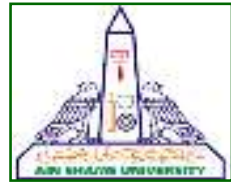

حث مقاومة نباتات الطماطم ضد فيروس تبرقش الاخان باستخدام الريبوفلافين

[89]

\author{
فريدة محمد محمود" - أحمد محسن بندق - ولاء خليفة - فوزى أبو العباس \\ قسم أمراض النبات - كلية الزراعة - جامعة عين شمس - ص.ب 68 - حدائق شبرا 11241 - القاهرة - مصر اهر
}

*Corresponding author: Faridamohamed@agr.asu.edu.eg

Accepted 5 December, 2020

أظهرت تأثير ايجابى على نمو النباتات سواء في حالة

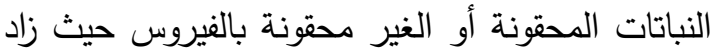

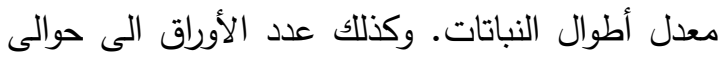
30 و 78\% على التوالي مقارنة بالكنترول المحقون.

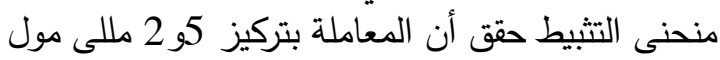

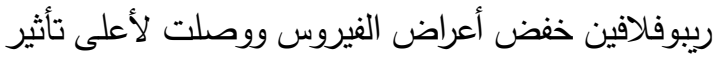

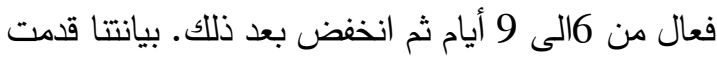
أكثرمن ذلك حيث أن مستوى التعبير الجينى لجين لجين الفينيل ألانين أمونيا لايز (PAL) و الكان الـ علامات على المقاومة الجهازية الدكتسبة (SAR) أزدادت سريعا في نباتات الطماطم المعاملة والمحقونة المعانة

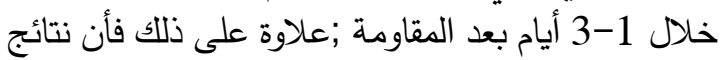

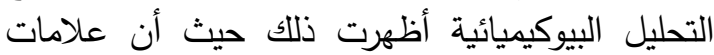
الدفاع والتى تتضمن كلا من انزيم البيروكسيديز (POD)

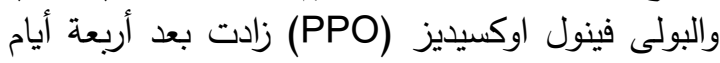

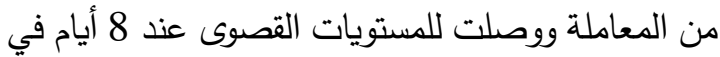

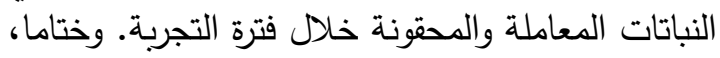
تحقق أن الريبوفلافين له تأثير شديد على الإلى فرة الإصابة

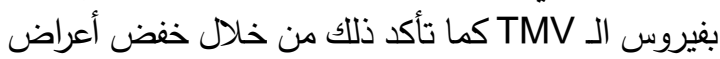
المرض مع حدوث التغيرات البيوكيميائية المرتبطة بتعظيم مقاومة النبات ضد الإصابة بفيروس ال TMV.

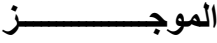

تستحث المقاومة الجهازية للنبات باستخدام مواد

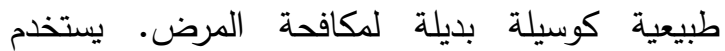

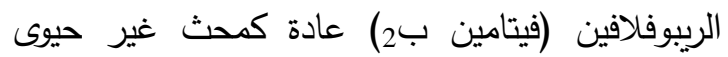

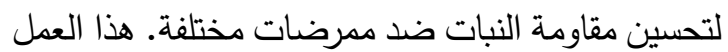

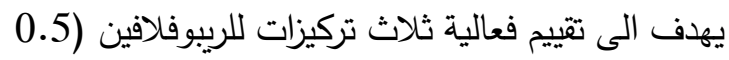

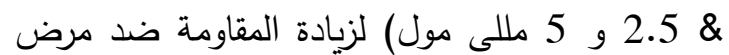

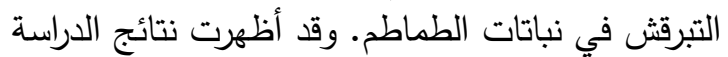

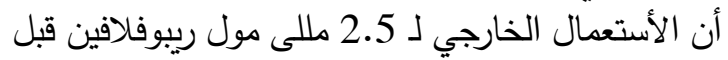
5 أيام من الحقن بالفيروس كان هو التركيز الأكثر فاعلية

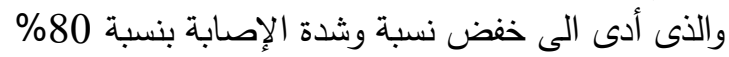

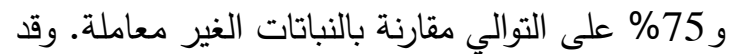

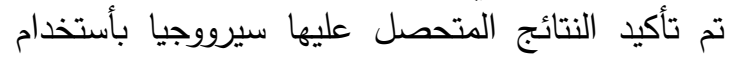
أختبار الأليزا والذى أوضتح أن 2.5 مللى مول ريبوفلافين بألين خفض التركيز النسبى للفيروس بنسبة النباتات المعاملة. كما تم تحديد التأثير على فلير فاعلية الفيروس من خلال تكون البقع المحلية على العائلئل

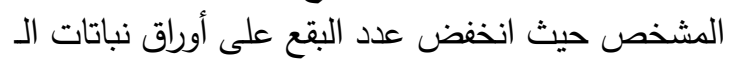
Nicotiana glutinosa أن المعاملة الخارجية بتركيز 2.5 مللى مول رببوفلافين لين لين 